\title{
TWO NEW SPECIES OF IMPATIENS (BALSAMINACEAE) FROM BATANG GADIS NATIONAL PARK, NORTH SUMATRA, INDONESIA
}

\author{
NANDA UTAMI \\ Herbarium Bogoriense, Botany Division, Research Centre for Biology-LIPI, \\ Jalan Ir. Juanda 22, Bogor 16122, Indonesia
}

\section{SUMMARY}

Two species of Impatiens (Balsaminaceae), I. sorikensis Utami and I. batanggadisensis Utami are described as new species. They are endemic for Batang Gadis National Park, North Sumatra.

Key words: Balsaminaceae, Impatiens, Batang Gadis National Park, new species.

\section{INTRODUCTION}

In a revision of Sumatran Impatiens, Grey-Wilson (1989) described 29 species of Impatiens from Sumatra. To this number Shimizu \& Utami (1997) added one new species, I. tujuhensis Utami \& T. Shimizu. In Sumatra Impatiens species are numerous in herbaceous undergrowth, especially in montane forest, along rivers and streams, and near waterfalls. During field work in June 2004, Utami et al. collected 2 peculiar Impatiens plants from Batang Gadis National Park, which is located in Mandailing Natal regency, North Sumatra Province. On returning to Bogor, West Java, I compared these two specimens with all the available herbarium material of Impatiens in our herbarium (Herbarium Bogoriense). As a result these two specimens seem to represent new species. These two taxa are obviously closely related, they can be separated in a number of characters, especially those of the indumentum of the plants, the leaf margin, the lower petal markings, and by the spur. Both species belong to section Megalocentron Warb. \& Reiche (1895). The two species are described below.

\section{Impatiens batanggadisensis Utami, spec. nov. - Fig. 1}

I. sidikalangensis Grey-Wilson affinis, sed petalo laterali forma et colore differt, calcari uncato distinguenda. - Typus: T. Tokuoka et al. T-680 (holo BO), Indonesia, North Sumatra, Mt Sorikmerapi, Batang Gadis National Park, Panyabungan, $1235 \mathrm{~m}$ alt.

Herbs to $60 \mathrm{~cm}$ tall, stems simple, glabrous. Leaves alternate, petiolate or upper ones sessile, petiole $0.5-1.5 \mathrm{~cm}$ long; lamina ovate to elliptic, $4-5.5$ by $1.5-2 \mathrm{~cm}$, base attenuate, margin crenate, apex acute, glabrous on both surfaces. Inflorescences terminal, usually with 2-4 flowers, flowers yellow-orange, marked with red on the lower part of the lateral united petal. Peduncles c. $6.5 \mathrm{~cm}$ long, glabrous. Pedicels c. $2 \mathrm{~cm}$ long. Lateral sepals 2 , ovate, c. 0.8 by $0.3 \mathrm{~cm}$, glabrous; lower sepal navicular, $1 \mathrm{~cm}$ long, $0.5 \mathrm{~cm}$ deep, abruptly constricted into a c. $1.5 \mathrm{~cm}$ long curved filiform spur, glabrous. 


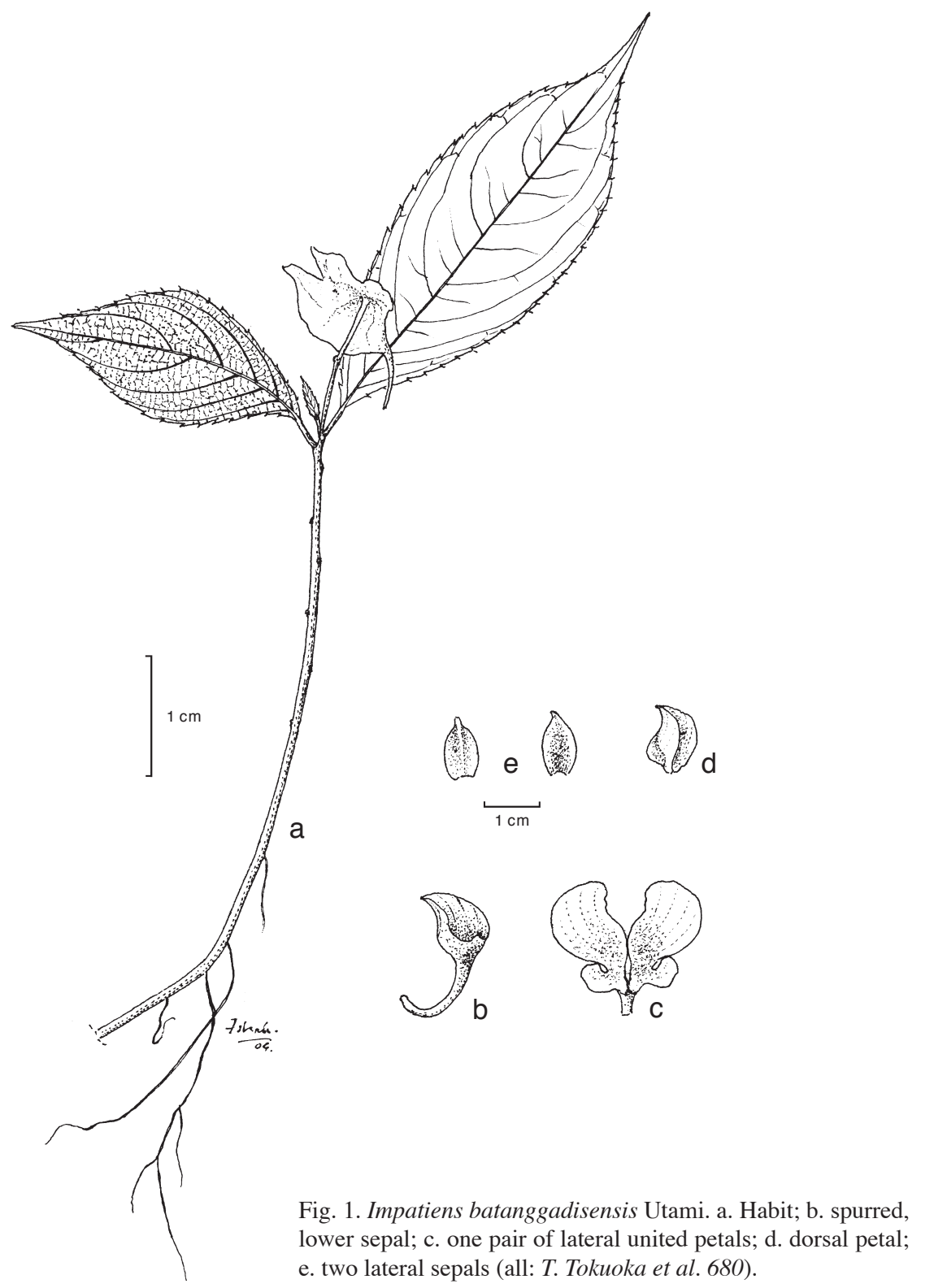

Dorsal petal cucullate, c. 1 by $0.5 \mathrm{~cm}$ wide, with a keel-like crest above, lateral united petals, c. $2 \mathrm{~cm}$ long; upper part of each pair obliquely obovate and with red markings, c. 1 by $0.5 \mathrm{~cm}$, lower petal of each pair \pm obovate, c. 1 by $0.8 \mathrm{~cm}$, emarginate. Ovary glabrous. Fruit capsule fusiform.

Distribution - Mount Sorikmerapi, Batang Gadis National Park, Panyabungan, North Sumatra. Endemic.

Habitat - Secondary forest. Altitude $1235 \mathrm{~m}$. 
Note - This interesting new species is quite distinct with its rather flat, yellow flowers with red markings on the bases of the two lateral petals, emarginate lower petals, and glabrous leaves. The specific epithet is derived from the name of the National Park, Batang Gadis.

\section{Impatiens sorikensis Utami, spec. nov. - Fig. 2}

I. pilosivitata Grey-Wilson arcte affinis, sed petalo laterali forma differt, foliis forma distinguibilis. - Typus: T. Tokuoka et al. 617 (holo BO), Indonesia, North Sumatra, Mt Sorikmerapi, Batang Gadis National Park, Panyabungan, $1235 \mathrm{~m}$ alt.

Herbs to c. $60 \mathrm{~cm}$ tall; stems rather thin, simple, finely pubescent. Leaves alternate, petiolate or upper ones sessile, petiole $0.5-1.5 \mathrm{~cm}$ long, pubescent with stipitate glands,

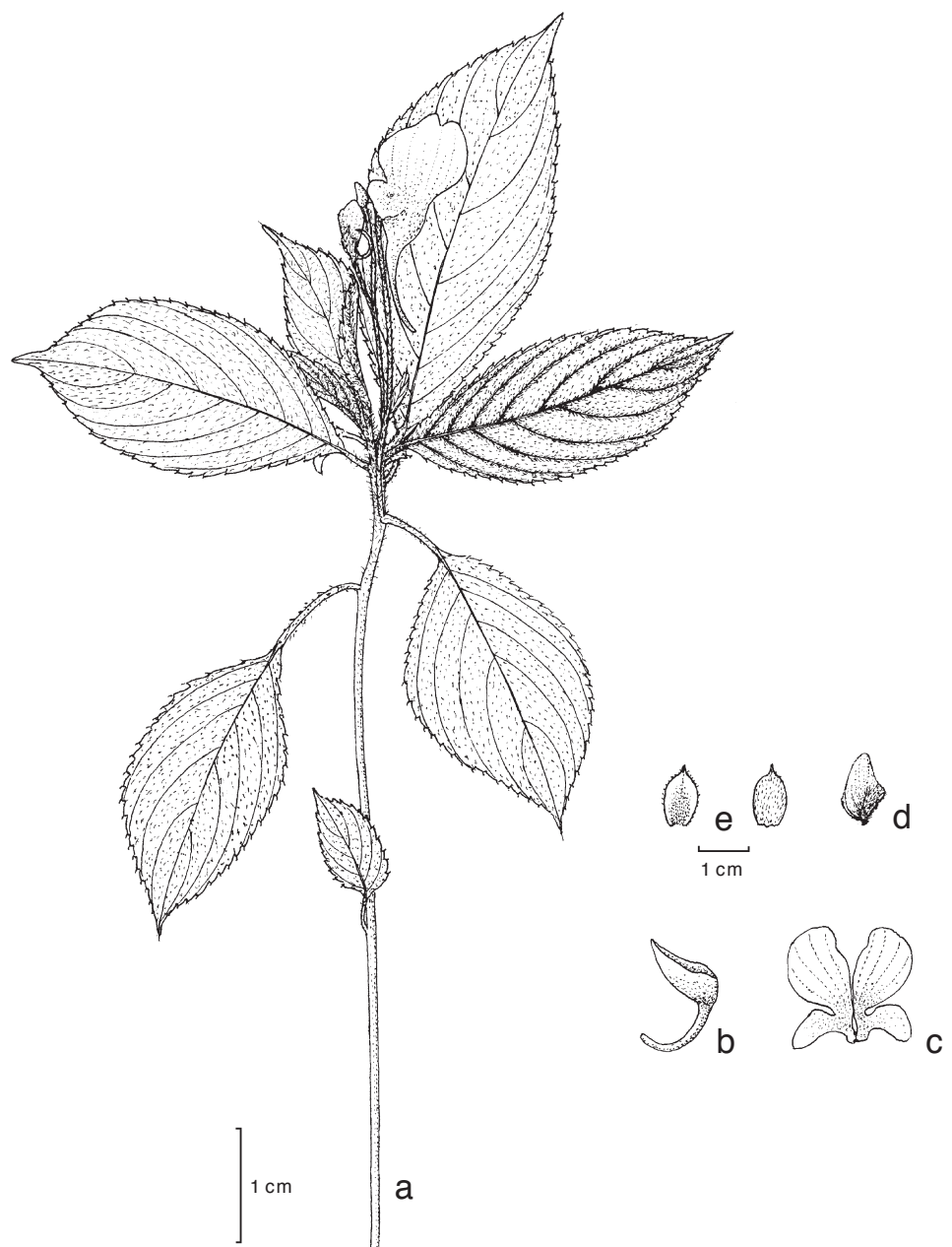

Fig. 2. Impatiens sorikensis Utami. a. Habit; b. spurred, lower sepal; c. one pair of lateral united petals; d. dorsal petal; e. two lateral sepals (all: T. Tokuoka et al. 617). 
c. $0.2 \mathrm{~cm}$ long; lamina ovate to elliptic, $1.5-5$ by $0.5-2.5 \mathrm{~cm}$, base attenuate, margin serrate, apex acuminate, pubescent on both surfaces, lateral veins 3-5 pairs. Inflorescences 2- or 3-flowered, racemes, flowers yellow-orange. Peduncle slender, $2-3 \mathrm{~cm}$ long, pubescent. Pedicels $1.5-2 \mathrm{~cm}$ long, pubescent. Lateral sepals 2 , ovate, c. $1 \mathrm{~cm}$ long, pubescent in the upper part; lower sepal navicular, $1.5 \mathrm{~cm}$ long, $1 \mathrm{~cm}$ deep, abruptly constricted into a c. $2 \mathrm{~cm}$ long, straight filiform spur, pubescent. Dorsal petal cucullate, c. 1.5 by $0.8 \mathrm{~cm}$, with a keel-like crest above, pubescent; lateral united petals c. 2.5 $\mathrm{cm}$ long; upper one of each pair obliquely obovate, c. 1 by $0.5 \mathrm{~cm}$ wide, lower one of each pair obovate, c. 1.5 by $1 \mathrm{~cm}$. Ovary glabrous. Fruit capsule fusiform.

Distribution - Mount Sorikmerapi, Batang Gadis National Park, Panyabungan, North Sumatra. Endemic.

Habitat - Secondary forest. Altitude $1235 \mathrm{~m}$.

Note - The specific epithet is derived from the mountain name, Sorikmerapi. Impatiens sorikensis has a distinctive look with its rather flat, yellow flowers and finely pubescent leaves and inflorescence. Impatiens sorikensis finds its closest ally in I. pilosivitata Grey-Wilson. They differ in a number of important aspects: the shape of the lateral petals, the colour of the flowers, and the shape of the leaves.

\section{ACKNOWLEDGEMENTS}

I would like to thank Suntory Flower Ltd. Japan for their financial support for this work. I would also like to acknowledge the help of various companions in our field work who greatly helped to find and process specimens, particularly Dr. Yasuyuki Murakami and Mr. Takeshi Kanaya of Suntory Flower Ltd., Japan, Dr. Toru Tokuoka of Kyoto University, Japan, Mr. Deden Girmansyah of Herbarium Bogoriense-LIPI, Bogor and Mr. Rusydi Tamin and Mr. P. Akhriadi of Andalas University, Padang. Thanks are due to Mr. Iskak of Herbarium Bogoriense-LIPI, Bogor for preparing the figures.

\section{REFERENCES}

Grey-Wilson, C. 1989. A revision of Sumatran Impatiens. Studies on Balsaminaceae VII. Kew Bull. 44: $67-106$.

Shimizu, T. \& N. Utami 1997. Three new species of Impatiens (Balsaminaceae) added to Flora Malesiana. Kew Bull. 52: 435-442.

Warburg, O. \& K. Reiche. 1895. Balsaminaceae. In: A. Engler, Die natürlichen Pflanzenfamilien III, 5: 390-392. 